Published as: Jacobo Grajales, J. 2020. A Land Full of Opportunities? Agrarian Frontiers, Policy Narratives and the Political Economy of Peace in Colombia. Third World Quarterly, 47(7), $1141-60$.

\title{
A Land Full of Opportunities? Agrarian Frontiers, Policy Narratives, and the Political Economy of Peace in Colombia
}

\author{
Jacobo Grajales
}

\begin{abstract}
In many post-war countries, the relative security brought to rural areas is construed by government officials and business actors as an opportunity for development. This is particularly true for marginal areas, where opportunities for economic development had previously been hindered by the threat of violence. This provides a favourable context for the construction of commodity frontiers. Through the case of Colombia, I show that one of the main challenges faced by frontier policy narratives amounts to differentiating wartime dispossession from peace-time legitimate accumulation. This poses intractable challenges to policy-makers and business actors, as it fuels the contradiction between peace-consolidation and post-war development.
\end{abstract}

Keywords: agrarian frontiers, post-conflict development policies, policy narratives, agribusiness, Colombia

\section{Introduction}

In war-torn countries, many people see peace - as unequivocal as the word may be - as a promise of material well being. This can be a powerful driving force behind peace agreements and consolidation policies. Nevertheless, material aspirations are no more homogeneous in post-war settings than at quieter times. ${ }^{1}$ As dominant actors and social groups strive to maintain and expand their influence, inequalities that were produced or worsened through violent means tend to

1 Berdal and Zaum, Political Economy of Statebuilding; Cramer, Civil War is Not a Stupid Thing; Distler, Stavrevska, and Vogel, "Economies of Peace"; Jennings and Bøås, "Transactions and Interactions"; Pantuliano, Uncharted Territory; Pugh, Cooper, and Turner, Whose Peace? 
reproduce themselves in a more peaceful and institutionalized manner. ${ }^{2}$ The fact that these struggles often take place against the backdrop of a free-market imperative ${ }^{3}$ grants a comparative advantage to those able to sail in the agitated waters of corporate capitalism. ${ }^{4}$ Arguably, corporations and wellconnected entrepreneurs may be better armed for thriving in such circumstances.

In countries with large and contentious rural spaces, a common trait of these scenarios is the production of agrarian frontiers. Frontiers are essentially a political construction. As highlighted in a recent essay by Rasmussen and Lund, 'they do not exist as a function of geography per se, but are brought about because new possibilities of resource extraction and use prompt new and competing claims on authority, legitimacy, and access'. ${ }^{5}$ Agrarian frontiers are construed through a process of representation, that portrays spaces as 'vacant' and 'open for colonisation'. ${ }^{6}$ Of course, this does not imply that such land really is vacant - but, most often, that it is exploited via means that are deemed to be archaic and unproductive. As such, land-accumulation is legitimized in the name of capitalist improvement. $^{7}$

Frontiers in these cases share a common point: they are promises of material prosperity, they are stories about development. They are, in short, policy narratives over the peace economy. The concept of policy narrative provides a useful lens here, as it highlights the power of ideas in the production of agrarian frontiers. Policy narratives are 'strategic constructions of a policy reality promoted by policy actors that are seeking to win (or not lose) in public policy battles' ${ }^{8}$ They are causal stories that suggest a course of action and a desirable outcome. ${ }^{9}$

While the production of agrarian frontiers is a common feature in the development of capitalism, ${ }^{10} \mathrm{I}$ will argue here that the very dynamics of peace-making tend to make frontier-production particularly problematic. On the one hand, in cases as variegated as Guatemala, ${ }^{11}$ Uganda $^{12}$ or Myanmar, ${ }^{13}$ the relative security brought to rural areas has been construed by government officials and business actors as an opportunity for development. On the other hand, these development prospects are rendered more complex by the characteristics of war economies. As one of the central features of contemporary armed conflicts is the intimate link between plunder and the development of capitalism, ${ }^{14}$ resource politics in post-war countries must answer the delicate question of the difference between spoliation and legitimate accumulation. This is exactly why the focus on policy narratives is important; stories about the promises of the agrarian frontier face the challenge of

\footnotetext{
2 Grajales, "Losing Land in Times of Peace."

Ottaway, "Rebuilding State Institutions in Collapsed States."

Klein, The Shock Doctrine.

Rasmussen and Lund, "Reconfiguring Frontier Spaces," 391.

Rasmussen and Lund, "Reconfiguring Frontier Spaces"; Wolford et al., "Governing Global Land Deals."

$\mathrm{Li}$, Land's End, 110; see also Hall, Hirsch, and Li, Powers of Exclusion.

Jones, Shanahan, and McBeth, The Science of Stories, 9.

Roe, Narrative Policy Analysis.

10 Bjork-James, "Hunting Indians"; Baretta and Markoff, "Civilization and Barbarism"; Lowenhaupt Tsing, "Natural Resources and Capitalist Frontiers"; Peluso and Lund, "New Frontiers of Land Control: Introduction"; Watts, "Accumulating Insecurity and Manufacturing Risk along the Energy Frontier"; Moore, Capitalism in the Web of Life.

11 Ybarra, 'Taming the Jungle'.

12 Martiniello, 'Social Struggles in Uganda's Acholiland'.

13 Woods, 'Ceasefire Capitalism'.

14 Cramer, Civil War is not a Stupid Thing.
} 
distancing post-conflict development from wartime land grabbing. How different this phase of accumulation is from previous cases of gunpoint spoliation? How dissimilar are these respectable business actors from previous characters of plunder and ransack?

Such a viewpoint provides a valuable contribution to the literature. As a matter of fact, a great wealth of scholarly literature has been produced on the ways in which frontiers generate new patterns of labour and resource exploitation. Extant works provide a refined understanding over the articulation between authority, legitimacy, and access, ${ }^{15}$ the commodification of the not-yetcommodified, ${ }^{16}$ and the articulation between legal and illegal orders. ${ }^{17}$ However, much less is known about the production of frontier narratives, their embeddedness in larger process of policy transformation and production, the articulation between policy-making, policy-networks, and policy -change, with the production of agrarian frontiers. Mobilizing an interdisciplinary framework that borrows both to policy analysis and political geography, this contribution aims to suggest some possible lines of research.

This objective is pursued through a detailed case study of Colombia. While Colombia features a much-hailed and internationally-advertised peace agreement, signed in 2016 between the government and the Revolutionary Armed Forces of Colombia (FARC) rebels, the country is also characterized by the strong political support enjoyed by its agribusiness development model. ${ }^{18}$ Moreover, armed conflict in Colombia was characterized by massive and violent land grabbing, in the hands of armed militias and their business associates, which bolstered and reproduced an extremely unequal agrarian structure. According to recent data, 69.5\% of producers occupy plots of less than 5 ha. Their properties cover only $5.2 \%$ of the arable land. On the other hand, $0.2 \%$ of producers cultivate plots of more than 1000 ha, which cover $32.8 \%$ of agricultural land. ${ }^{19}$ While the relation between land inequalities and land grabbing is far from straightforward, ${ }^{20}$ there is a wide scholarly consensus on the important contribution of armed violence to the reproduction of a highly unequal agrarian order. ${ }^{21}$

The 2016 peace agreement promised to provide a partial response to rural poverty and marginality. ${ }^{22}$ However, not only most of its distributive dimension has been dismissed, ${ }^{23}$ but the very core of its purpose - to provide stability - is growingly at risk. ${ }^{24}$ While security levels in most of the country have improved over the last decade, selective violence still threatens community leaders and political activists. As the largest armed group - the FARC - agreed to demobilize, the ELN guerrilla (National Liberation Army), as well as FARC dissident groups and paramilitary militias, still exert brutal rule in large parts of the Colombian countryside. ${ }^{25}$ Demobilized FARC commanders recently

15 Rasmussen and Lund, "Reconfiguring Frontier Spaces."

16 Watts, "Accumulating Insecurity and Manufacturing Risk along the Energy Frontier."

17 Ballvé, "Narco-Frontiers."

18 Fajardo, Las guerras de la agricultura colombiana, 1980-2010.

19 DANE, "Tercer Censo Nacional Agropecuario."

20 Gómez, Sánchez-Ayala, and Vargas, "Armed Conflict, Land Grabs and Primitive Accumulation in Colombia."

21 Reyes, Guerreros y campesinos; Machado and Meertens, La tierra en disputa; Londoño, Tierras y conflictos rurales; Gutierrez Sanín and Vargas Reina, El despojo paramilitar y su variación; Meertens, Elusive Justice.

22 McKay, "Democratising Land Control."

23 García Trujillo, The Havana Peace Agreement.

24 OCHA, 2019 Humanitarian Needs Overview: Colombia; PARES, Más sombras que luces.

25 Maher and Thomson, "A Precarious Peace?" 
declared that they had returned to armed struggle, while they accused the state of betraying the peace accord. In many places, wartime plunder has simply been replaced by less visible forms of dispossession. ${ }^{26}$ The police and the military's approach to social protest is deeply entrenched within counterinsurgency practices, and the regional political and business elites were in many cases direct beneficiaries of paramilitary repression and dispossession. ${ }^{27}$ More than strictly 'post-conflict', the Colombian situation might thus be better seen as 'no peace, no war', ${ }^{28}$ 'interwar' ${ }^{\text {'2 }}$ or 'low-intensity disorder'. ${ }^{30}$

Policy narratives linking peace and agrarian frontiers predate the recent peace talks and peace agreement. They became particularly influential in the late 1990s, at a moment when armed violence reached the highest point of the recent decades, and primarily concerned a territory that epitomizes frontier politics: the Orinoco plains, a savanna region covering around 250,000 square $\mathrm{km}$ between the Andes, the Amazonian jungle and the Venezuelan border (figure 1). During the last decade, these narratives evolved to adapt to the changing political context, as land became a central issue of the peace-making agenda. This adaptation was fraught with controversies and political struggles that resulted in 2015 in the vote of a law creating special agro-industrial zones, known as Zidres (Zones of Economic and Social Development Interest). This contribution is not focused on the effects of this policy, as its implementation phase only started in mid-2018. It is rather interested in tracing the actors and places where a frontier narrative was produced and transformed.

To pursue this objective, I will draw primarily on interviews with policy-makers, business-sector representatives and NGO professionals $(n=50)$, but also policy documents and news reports. Interviews were conducted in the cities of Bogotá and Villavicencio in July 2015, October 2017, and November 2019. Data from a previous project, which concerned the links between paramilitary militias and the state, ${ }^{31}$ is also used. As in most of Colombia, data about the characteristics of land property and land markets in the region is extremely problematic. Land registries lack in $28 \%$ of the territory, and are acknowledged to be outdated in $64 \%$ of the territory, ${ }^{32}$ thus being unable to reflect the evolution of land ownership. The only reliable source of data is the 2014 agrarian census; it provides me here with the necessary information to sketch the social portrait of the region. However, as the previous agrarian census dates from 1970, it is impossible to study recent transformations based on this source.

This research is a part of a larger project aimed at producing a comparative analysis of the place of land and agricultural policies in the political economy of post-conflict development. ${ }^{33}$ The first section of the article traces the story of a policy narrative that articulates stabilization and business opportunities. The second section lays out how this corporate-peace narrative was challenged, both from within and without the state, and how policy actors managed to neutralize the critiques and finally prevail.

26 Ojeda, "Green Pretexts"; Ojeda et al., "Paisajes del despojo cotidiano."

27 Grajales, "Violence Entrepreneurs."

28 Richards, New War.

29 Debos, Living by the Gun in Chad.

30 Gill, A Century of Violence.

31 Grajales, Gobernar en medio de la violencia.

32 DNP, "CONPES 3859".

33 Grajales, "Losing Land in Times of Peace". 
Figure 1. The Orinoco plains, including zones mentioned in the text

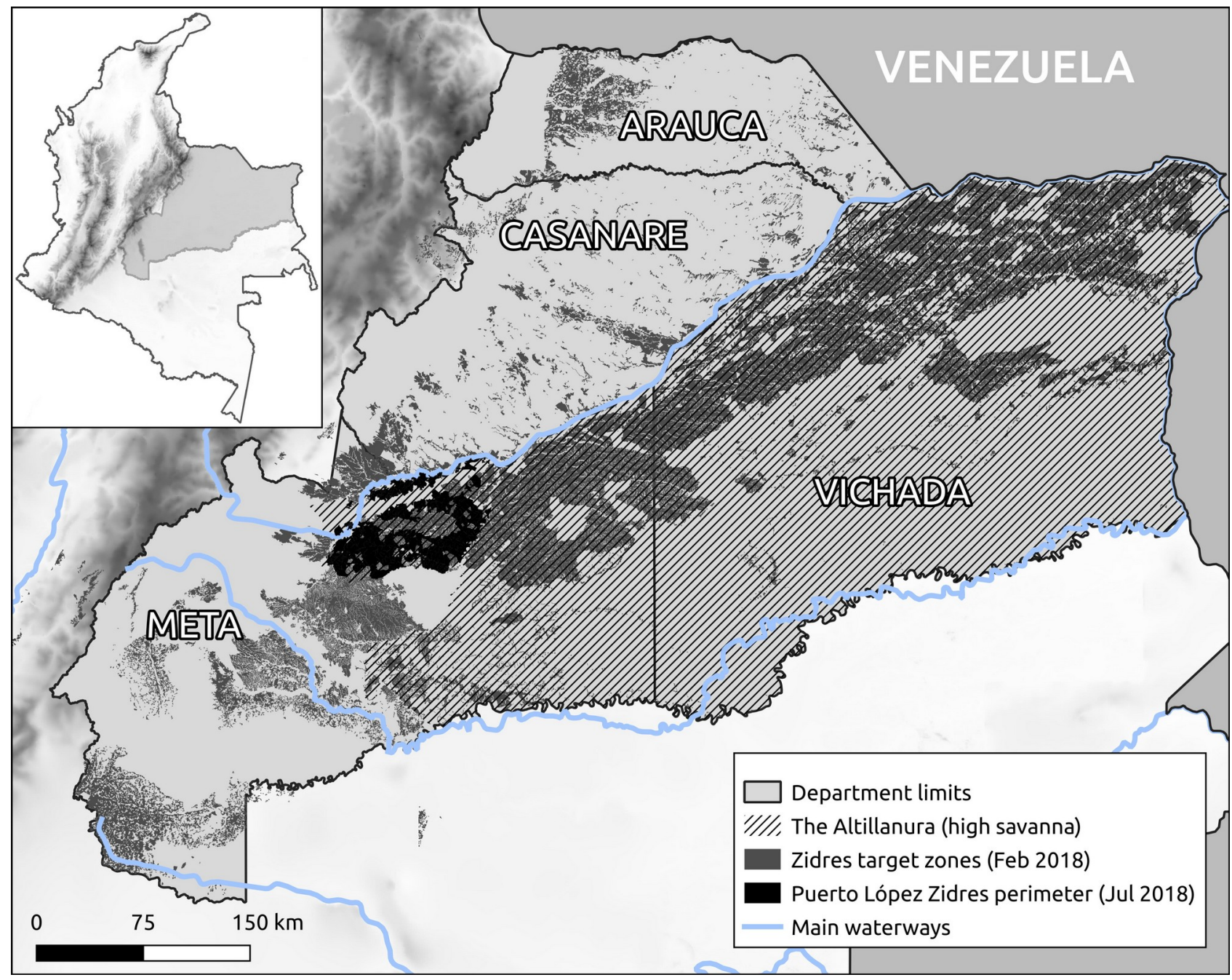

The author, compiled from data from Naturalearthdata.com and sipra.upra.gov.co (both public domain)

\section{Peace and business opportunities}

The end of the 2000s were characterized by increasing corporate interest for the Orinoco plains, as security conditions favoured investment from foreign and Colombian firms alike. However, investment in this region was made difficult by an anti-accumulation legislation, that sought to favour small peasants over large corporations. This resulted in massive fraud, as corporations tried to circumvent the law to pursue with their business activities. Such strategies were largely made possible by the secretive and unefficient land governance that characterizes the Colombian rural areas. The following pages elaborate on this link between state (in)action and illegal corporate strategies. 


\section{Orinoco: from the margins of the state to the centre of post-war development}

Spanish (prior to 1819) and Republican colonization of Orinoco resulted in land being accumulated on a massive scale by absentee cattle ranchers, at the price of the displacement and annihilation of Indigenous communities. ${ }^{34}$ While geographic, climate and sanitary conditions limited the flow of settlers, ${ }^{35}$ attempts to develop the region had been intermittent since the middle of the XIXth century. These were guided by an imaged portrayal of the Orinoco as 'a region of untold wealth and resources that within a few short years would become the heartland of Colombian prosperity'. ${ }^{36}$ These endeavours were frustrated by lack of state capacity (and will), and by the disconnection between grandiose representations of development and the meagre reality of state elites' commitment to the region.

Orinoco entered the contemporary cycle of armed violence in the mid-1980s. Druglords and landed elites created paramilitary militias in response to social movements, peasant activism and leftist parties. ${ }^{37}$ In the second half of the 1990 s, Orinoco became one of the primary targets of a new paramilitary confederation, the United Self-Defence Forces of Colombia (AUC). The region was affected by competition for the coca-growing areas of the foothills and the neighbouring tropical forest, a long-time FARC stronghold. The activities of oil-extraction companies, both domestic and foreign, were a further incentive for rent-seeking.

From 2002 onwards, the government launched a security-consolidation policy. Armed-group activity, kidnapping for ransom and racketeering plummeted, which encouraged increase in the production of commodities such as palm-oil and rice. This converged with the policy-making sector in Bogota, where influential actors were promoting the idea that Orinoco was a promising agribusiness frontier.

In 2004, the former chair of the Colombian Farmers Society (SAC), Carlos Gustavo Cano, was appointed Minister of Agriculture. Upon his arrival in office, he launched a study on the prospects for the exploitation of the Orinoco, while mobilizing various government agencies responsible for agricultural research. For instance, Corpoica (the Colombian Corporation for agricultural research, today called Agrosavia) was tasked with a study on the characteristics of Orinoco's soil and the possible methods for implementing agricultural production. ${ }^{38}$ This was led in coordination with foreign agencies. Since Orinoco's soil is similar to that of the Cerrado, the Brazilian hotspot for agribusiness development, Cano spurred a partnership with the major Brazilian agricultural research centre, Embrapa. ${ }^{39}$

From its position at the margins, Orinoco was becoming a centrepiece of projects pursuing the expansion of agrarian capitalism. Among the first illustrations of this imaginary were the discourses directed towards hypothetical foreign investors. The government invested great effort to attract foreign investment, at the cost of massive public expense. This is well-illustrated by the Gaviotas project, a 150000 ha. public-private partnership meant to produce tropical pine, rubber and palm-

34 Rausch, A Tropical Plains Frontier.

35 Rausch, The Llanos Frontier.

36 Rausch, Territorial Rule, 5.

37 Dudley, Walking Ghosts; Riveros Gómez, Pueblos arrasados.

38 Interview with Alvaro Uribe Calad, former Executive-director of Corpoica, Bogota, November 2019.

39 Interview with Carlos Augusto del Valle. SAC deputy director. Bogotá, July 2015. 
oil. A first tranche of US\$ 360 million was devoted to clearing the land and building the necessary infrastructure. Benefits promised to investors included subsidies and tax exemptions, particularly for foreign companies. A brochure, distributed by the President's office, advertised the project under the title 'The renaissance of the Orinoco river savannas: a Colombian mega-project for the world' ${ }^{40}$

While these state-run efforts were never conclusive, private-sector projects began to be implemented during this period. One of the first companies to settle was the Aliar Group, which launched a 16,000 ha. farm called El Brasil in 2003. Aliar produced soy and maize, which are mainly used to feed poultry and pigs raised on-site. ${ }^{41}$ Agribusiness projects were settled in large numbers later in the decade. In 2008, the Monica group, a Brazilian cereal producer, acquired 13,000 ha. of land. In 2010, the global agrogiant Cargill acquired 52,000 ha., while announcing a project aiming at eventually exploiting more than 90,000 ha. $^{42}$

\section{Playing with the law}

While these land acquisitions were apparently legitimate business operations, most of them were legally flawed. ${ }^{43}$ The largest part of Orinoco's land was protected by an anti-accumulation legislation dating back from 1994. Most of this land had never been registered and was therefore considered as belonging to the national domain. According to the Lands Act of 1994 (Law 160), agricultural land in the national domain must be exclusively used for distribution within the agrarian reform policy. ${ }^{44}$ As such, beneficiaries were expected to be land-poor or landless peasants. Moreover, according to this law, the surfaces allocated must not be accumulated beyond a certain area, known as the Family Agricultural Unit, or UAF (that is defined in each region depending on the local conditions of production). When land was sold by the original beneficiary, the purchaser was required to comply with the same accumulation limits; the goal was to prevent large entrepreneurs and speculators from attaining a dominant market position. In areas of agrarian reform, the land market was expected to remain limited to peasant producers.

Consequently, most of the land of Orinoco was beyond the reach of large private investors. Agribusiness firms and corporate associations were extremely critical of this law. From the early 2000 s, as the economic potential of areas targetted by the security consolidation policy were advertised by the government, lobbyists from the sector adamantly pushed for a reform of the law. They pointed at the incoherence between the official discourse, which portrayed Orinoco as a land full of opportunities, and the realities of a legal framework that severely limited investment possibilities. $^{45}$

Subsequent administrations tried to respond to the business sector requests, by introducing legal exceptions for agribusiness actors. In each case, these attempts were frustrated by the opposition of

40 Ministerio de Agricultura y Desarrollo Rural. The Renaissance of the Orinoco River Savannas: A Colombian MegaProject for the World. Bogota: Gobierno de Colombia, 2004.

41 Verdad Abierta, "Grupo Aliar-La Fazenda responde por las tierras de 'El Brasil', en Puerto Gaitán."

42 Salinas Abdala, "El caso de Colombia"; Somo and Indepaz, Reconquering and Dispossession in the Altillanura; Mesa Copartes Misereor, Desplazar y despojar; FAO, Concentración y extranjerización de tierras productivas en Colombia.

43 Oxfam International, "Divide and Purchase."

44 Machado, La reforma rural.

45 Interview with Carlos Augusto del Valle. 
the Constitutional Court. In 2007, Alvaro Uribe's government promoted a 'Rural Development Act'; the text included an exception granted to large agribusiness firms to implement 'high-impact agro-industrial projects' in lands protected by the anti-accumulation legislation. The whole act was deemed unconstitutional in 2009. In 2011, the Juan Manuel Santos government introduced a similar legal provision in its National development plan, a programmatic law covering various aspects of social and economic development. That specific measure was revoked by the Court.

While the business establishment's legislative influence strategy proved unsuccessful, various corporations developed complex strategies for circumventing the law; the most common method was to acquire land through different, formally independent firms. Each of these 'independent' companies complied with the individual surface limits. In practice, they belonged to the same holding. This came to be known as the 'divide and purchase' strategy. ${ }^{46}$ The method was no secret. In 2009, when he was interviewed by an agribusiness journal, the chair of the cereal producers' organization openly acknowledged the use of such legal manoeuvres; he claimed that

'in order to acquire 13,000 ha. of land in El Chaparral, Monica [the company] had to set up six companies, the only way to comply with the provisions of Law 160 of 1994 [...] In short, domestic and foreign investors are limited in their plans to purchase large estates, as they are unable to acquire surfaces above the Family Agricultural Unit. That specific fact discourages investment, as it requires the creation of several companies, headed by associates or third parties'. ${ }^{47}$

This mindset would come into conflict with the transformations in the land policy agenda from 2010. Influential policy actors framed these such business strategies as illegitimate forms of accumulation, and as one of the many signs of the inefficient and corrupt forms of land management that had fuelled the armed conflict. The following section shows how these corporate strategies became the target of public criticism, and how a narrative of frontier-production was reshuffled as a response to these accusations.

\section{A new narrative for times of peace}

In 2010, a convergence of civil society mobilization, foreign donor support, and changes in state power gave place to a progressive agenda in rural politics. ${ }^{48}$ The vote of a Victims and Land Act in 2011 recognized the magnitude of the land spoliation problem and the responsibility of the state in protecting the rights of vulnerable peasant, Afro-Colombian and indigenous populations. ${ }^{49}$

Agribusiness in the Orinoco plains was not the primary target of the promoters of this agenda, who were much more focused in paramilitary militias' land grabbing. ${ }^{50}$ However, as the policy debate broadened to embrace the objective of more transparent and accountable land-governance, legal schemes such as the 'divide and purchase' strategy would become a primary policy issue. In the face of accusations of land accumulation the business establishment added forces with insider policy actors to push for an adapted narrative, which attempted to depoliticize the controversy and

46 Oxfam International, "Divide and Purchase."

47 'Detrás de Mónica otros vendrán', El Cerealista, February 2009.

48 García Trujillo, The Havana Peace Agreement.

49 Dávila, "A Land of Lawyers, Experts and 'Men without Land”; Gutiérrez-Sanín, ¿Qué hacer con el tierrero?

50 Gutiérrez-Sanín, Peña-Huertas, and Parada-Hernández, La tierra prometida. 
impose the idea that only large corporations were sufficiently well equipped to face the challenges of agricultural development in Orinoco.

\section{Moralizing land ownership}

From the late 2000s, social mobilizations denouncing the violent grabbing of peasants' land had been growing in influence. A debate was opened over the amount of grabbed land, with estimates varying over a large spectrum from 1 to 10 million hectares. ${ }^{51}$ Judges were also getting involved, as inquiries about the alliances between paramilitary militias, civil servants and business actors started being launched. ${ }^{52}$ Government officials working in assistance programmes for internally displaced persons (IDPs) were also acting from within the state. ${ }^{53}$ They enjoyed the support, not only of $\mathrm{NGOs}^{54}$ - but also of influential donors, such as the European Union, the UNDP and the World Bank. ${ }^{55}$

The presidency of Juan Manuel Santos (2010-2018) provided a favourable political environment for this mobilization. One of the most symbolic bills in the early years of the administration was the Victims and Land Act, enacted in 2011; the law provided the possibility for internally displaced people to recover the land that they had lost through dispossession and violent land-grabs. In 2012 , the government announced the formal opening of negotiations with the FARC. In 2013, the two parties reached an agreement on the first point (out of six), dealing precisely with agrarian issues. The agrarian point provided for the implementation of a 'Comprehensive rural reform' that included the distribution of 3 million hectares of land to peasants, Afro-Colombian and Indigenous communities, as well as the formalization of 7 million hectares. It also included a large plan of social and economic investment in rural areas and the support of family agriculture.

One of the important consequences of these political transformations was to highlight that land grabbing was not only a matter of violent and outright spoliation, but also a consequence of the lack of direct state presence, widespread corruption, and weak administrative capacity. The implementation of ambitious policies such as land restitution and the Comprehensive rural reform required a complete institutional restructuring of the agrarian sector, including judicial redress and 'capacity building'. ${ }^{56}$

These were advertised as top policy objectives when, in August 2010, President Santos appointed Juan Camilo Restrepo - a moderate conservative - as Minister of Agriculture. From Restrepo's first months in office, he was tasked with the implementation of the land-restitution policy. ${ }^{57}$ This endeavour required addressing the corruption of existing agencies. One of the top priorities was the

51 Garay-Salamanca, El reto ante la trajedia humanitaria del desplazamiento forzado, 45.

52 Regarding the rationale of these enquiries see: Grajales, "Land Grabbing, Legal Contention."

53 Estrada and Rodríguez, "La política de tierras para la población desplazada 2001-2011.”; Dávila, "A Land of Lawyers, Experts and 'Men without Land."'

54 Interview with Hugo Gómez, Programme Manager at Mercy Corps, Bogota, July 2015.

55 Interview with Ivonne Moreno, Senior consultant, World Bank, Bogota, October 2017; Interview with María Lizarazo, National Coordination Officer, UNDP, Bogota, July 2015; Interview with Johnny Ariza, EU Cooperation Officer, Bogota, July 2015.

56 Interview with Diego Mora, Deputy-director at the DNP (National Planning Department), Bogota, October 2017; Interview with Margarita Varón, former special advisor at DNP, Bogota, November 2019.

57 Restrepo and Bernal, La cuestión agraria. 
reform of the Colombian Institute for Rural Development, or Incoder, ${ }^{58}$ arguably one of the most corrupt and inefficient institutions of the land governance sector. ${ }^{59}$ Restrepo appointed a new Incoder director in April 2012. The appointee was Miriam Villegas, who, while having an elite background, was a widely-recognised activist, who had worked for 15 years in grass-roots peacemaking programmes. Her appointment was illustrative of an unprecedented opening-up of Incoder to social movements and NGO circles, in both top and middle-management positions. ${ }^{60} \mathrm{~A}$ few months earlier, Restrepo had appointed Jheniffer Mojica, a former NGO executive, as DeputyDirector. ${ }^{61}$ Young professionals hailing from an NGO background thus joined the Incoder staff. For many of these, it was the first time that they had taken up public-sector jobs ${ }^{62}$. With the aim of strengthening the management's capabilities for cleaning-up the institution, Mojica was granted the possibility to recruit external legal advisors, mostly lawyers specialised in criminal law, who constituted a kind of 'internal police force within the institution' ${ }^{63}$

The first inquiries led by this new team brought to light the collusive relationships between politicians, heads of local divisions, paramilitary chiefs and business-people. Many cases were found in which these various actors had conspired to legalise the violent dispossession of land belonging to forcibly displaced people, or had collaborated in order to cover up the illegal accumulation of public-domain land. Within the first months of Mojica and Villegas' terms in office, more than 900 investigations were opened by the Attorney General's Office on the basis of information provided by Incoder management. Other monitoring institutions, namely the General Inspector (Procuraduría General de la Nación) and the General Accounting Office (Contraloría General de la República) were also involved. ${ }^{64}$

These investigations ran up against the case of Orinoco's 'divide-and-purchase' corporate strategy. Under the leadership of Mojica and Villegas, Incoder documented cases of illegal landaccumulation by Colombian agribusiness leaders such as Manuelita, regional corporations like Brazil's Monica, and global giants such as Cargill. ${ }^{65}$

In addition, other state agencies were becoming aware of the multiple manoeuvres used to circumvent the anti-accumulation legislation in Orinoco. While delivering legal coverage, the 'divide and purchase' strategy offered further advantages, as it increased these companies' capacity to access state subsidies. Each front-company could file an individual demand for state subsidies, regarding projects that were distinct only on paper. This amounted to embezzling public funds. Upon discovering the scheme in 2013, the regulatory watchdog (Superintendencia de sociedades), applied fines of up 800.000 euros. $^{66}$

58 Incoder was eventually replaced by the National Land Agency (ANT), which has a larger mandate over land administration. ANT has been tasked with the distribution and formalization of land within the framework of the Comprehensive rural reform.

59 Restrepo, Implementación de la politica integral de tierras (2010-2013).

60 Interview with Miriam Villegas, Bogota, November 2019.

61 Interviews with Jhenifer Mojica, Bogota, July 2015 and October 2017.

62 Interview with former Incoder staffer, Bogota, July 2015.

63 Interview with Jhenifer Mojica; interview with Andrés Bermúdes, journalist at the La Silla Vacía web magazine Bogota, July 2015.

64 Ibid.

65 Interviews with Mojica and Villegas.

66 See for instance the ruling for the case Finagro v/ Mónica Colombia SAS et al., No. 2012-801-070 
Official scrutiny was reinforced by inquiries coming from Congress. This was spurred by Congressman Wilson Arias, a member of the Chamber for the 2010-2014 legislature, who sat on the benches of the Alternative Democratic Pole (PDA), the main left-wing party at the time. Arias is a former trade union leader from the Cauca Valley, Colombia's first agro-industrial region, and the cradle of some of the most powerful corporations of the sector. Shortly after he was elected, Arias commissioned his staff to carry out surveys of the investments made by agro-industrial companies in Orinoco. They managed to identify large land purchases by fifteen corporations that were applying the divide-and-purchase strategy. ${ }^{67}$

NGO inquiries were also shedding light on corporate fraud. In September 2013, Oxfam published the first survey on land-accumulation in the Orinoco. Its main target was Cargill; in order to accumulate more than 52,000 hectares, the global giant had created thirty-six front-companies with 'the same sole board member, one principal legal representative, and secondary legal representation shared among three people'. ${ }^{68}$ Other, smaller organizations followed this lead, such as Colombia's Indepaz and Netherlands' Somo. ${ }^{69}$ These inquiries responded to a general trend in NGO circles, with the agrarian agenda becoming a central concern of most human rights and peace-making organisations. ${ }^{70}$

Investigations from state agencies, Congress and civil society organizations were not disconnected from each other. Congressional staffers, Incoder officials and Oxfam executives interviewed all claimed to have shared information among themselves concerning their ongoing inquiries. Not only were some of them were previously acquainted; they also had a common interest in shedding light on the accumulation cases.

The convergence of these trends towards exposure gave the scandal a high profile. In August 2013, Senator Jorge Robledo, a major figure from the left, called for a debate in Congress to present the results of Arias' investigations. He focused on one of the legal counsels for agribusiness firms, that was purportedly at the origins of the 'divide-and-purchase' strategy: the Brigard \& Urrutia law firm. The angle chosen was deeply personalized, as one of the firm's top associates was Carlos Urrutia, a close friend of the President and ambassador to Washington. In Robledo's speech to Congress, raising the issue of land-grabs was a shortcut for shining the spotlight on the corruption of a globalized elite. ${ }^{71}$

Throughout these conflicts, Orinoco epitomized the contradictory forces at play in Colombian postconflict development policy-making. For opposition politicians, NGO professionals, and a group of committed officials, the region portrayed the consequences of weak land-governance and corruption. The lack of administrative capacity was believed to have created a context favourable for land-accumulation in the hands of corporations. In the opposite camp, supporters of the frontier narrative saw the Orinoco plains as a land full of opportunities, an area kept at the margins of

(Superintendencia de sociedades. October 16, 2013).

67 Interview with Carlos Suescún, congressional staffer for congressman Arias, Bogota, July 2015.

68 Oxfam International, "Divide and Purchase," 18.

69 Somo and Indepaz, Reconquering and Dispossession in the Altillanura.

70 Interview with Aida Pesquera, country director at Oxfam, Bogota, July 2015.

71 A similar configuration is described by Schlimmer in the case of Tanzania. Schlimmer, "Talking 'Land Grabs' is Talking Politics." 
capitalist development for decades and now made available for agro-export activities. The next section will show how the second interpretation prevailed.

\section{Producing a new narrative}

Those who collaborated in bringing a hitherto technical matter of land-investment to the forefront of the news agenda hoped that the conjunction of accusations would spur a reaction from the executive branch. There was indeed a reaction, but it consisted in a violent backlash against the partisans of scrutiny operating within the state, namely Minister Restrepo and Incoder executives Villegas and Mojica. The personal attack against the president, and the fact that part of the information in this case came from within state institutions, were interpreted by members of the presidential majority in Congress and by close advisers to the Executive as a political attack. ${ }^{72}$ The downturn in the political climate led to the resignation of Minister Restrepo, as well as of Incoder's Director and Deputy Director. The latter was even subjected to legal action.

This was, however, not the only outcome of the controversy. Those who led the inquiries had hoped that their findings would push the government to admit that the law was being violated on a massive scale in Orinoco. To the contrary, the case spurred a conservative reaction, one that contributed to setting the boundaries between legitimate accumulation and spoliation. While investigations against corrupt officials or paramilitary mobsters were seen as legitimate law-enforcement operations, the attempts to dig into corporate accumulation were received with great hostility. In the words of Deputy Director Mojica:

'When the scandal over the links between Riopaila [one of the corporations involved in land-accumulation] and Ambassador Urrutia exploded, the presidency asked us for a report. We had been investigating for a long time. So we presented all the elements to the President. He told us it couldn't continue. That the priority here was investment and delivering legal security to investors. He said, "One thing is to prosecute Castaño, Carranza or Mancuso [paramilitary leaders], another thing is to attack good people". When we [she was accompanied by Incoder's Director] left his office we realized that we had to pack up' ${ }^{73}$

This quotation is not only illustrative of a transformation in the political climate, but it also sheds light onto the kind of arguments that were advanced by those who defended the frontier narrative. As far as state officials, business representatives and politicians were concerned, the newlyimproved security situation in Orinoco should have encouraged a more proactive policy to attract investors. From that standpoint, the 'divide-and-purchase' scandal was a turning point. It marked the victory of the frontier narrative. The vision of Orinoco as a zone of expansion for agribusiness activity would become official policy over the following years. However, this would need a reshuffled frontier narrative.

In the months that followed the land-accumulation scandal, the problem of land accumulation was gradually reframed. Influential representatives of agribusiness, but also academics and politicians, pushed for a depoliticized and technical narrative. The primary issue was not among whom the lands of the Orinoco should be distributed, but for what purposes. The availability of land in the

72 Interview with Miriam Villegas.

73 Interview with Jhenifer Mojica. 
region entailed opportunities for economic development, food, and agro-commodity production. In policy-making circles, the difficulty was how these potentialities could be attained. The idea that peasant agriculture was simply unfit to meet the technical challenges posed by the geographical and geological characteristics of Orinoco was gradually imposed.

The point of departure of this new narrative was identifying the region's potentialities, and contrasting these with the massively under-efficient exploitation. In January 2014, experts at the Department of National Planning (DNP), a highly influential institution placed directly under the President's control, released a report arguing that less than $3 \%$ of the region's land was used for agriculture: ${ }^{74}$ extensive and very poorly-equipped cattle-breeding occupied lands that would be better dedicated to other uses. They argued that this had a twofold explanation. Firstly, an environmental one: Orinoco's soils are poor in nutrients, highly acidic, and rich in aluminium. Further, the region features a long dry season that can last for more than four months and offers very low rainfall levels. ${ }^{75}$ Secondly, transportation infrastructure is poorly maintained and scarcely available. In Vichada - one of the hotspots of land-accumulation - there are $1660 \mathrm{~km}$ of roads - but only $39 \mathrm{~km}$ of these are paved. ${ }^{76}$ This results in prohibitive commercialization costs, amounting to $21 \%$ of the aggregated cost. ${ }^{77}$

The DNP's endeavour in analysing the region's potentialities and obstacles for development was dovetailed by a small but influential division of the Ministry of Agriculture, the Unit for Rural and Agricultural planning (UPRA), which had been created in 2011 to 'enhance competitiveness and efficiency in agriculture'. ${ }^{78}$ Both institutions joined efforts to precisely determine the suitable perimeter for a development policy in Orinoco. They clearly differentiated the zones suitable for agricultural activities, the core of which was the savanna plateau (Altillanura) located on the right bank of the Meta river (figure 1). As opposed to other areas of the Orinoco, the Altillanura has no natural protected areas and-as opposed to the left bank of the river-is not affected by seasonal flooding. ${ }^{79}$

For agribusiness representatives, the DNP and UPRA diagnosis echoed their core argument: peasant agriculture in these conditions was simply impossible; only large corporations have the financial capacity for doing business in Orinoco. They could pay for the onerous operations required by the chemical features of the soil-up to 3000 euros according to some experts. They were able to overcome transportation difficulties through scale economies. And they even might contribute to building roads and ports - if the government provided the right fiscal incentives. ${ }^{80}$ This narrative was echoed by the organization of a series of policy forums, the first of which was convened in May 2014 on the subject of 'Land in productive and sustainable development for Orinoco in an open market environment'. This was jointly hosted by the University of Los Andes, one of the most select private institutions of the country, and Riopaila-Castilla, an agribusiness giant and one of the main figures of the accumulation scandal.

74 DNP, “CONPES 3797,” 14.

75 DNP, 15.

76 DNP, 24.

77 Gaviria Muñoz, "Presentacion. Plan maestro de la Orinoquia."

78 Interview with Dora Inés Rey, UPRA deputy director, Bogota, October 2017.

79 DNP, “CONPES 3797"; UPRA, "Planificación Regional: Altillanura."

80 Interview with Carlos Augusto del Valle. 
These policy forums saw the consolidation of a further argument. Agribusiness investors were willing to overcome the environmental and geographical obstacles to investing in Orinoco, but they were hampered by the land-accumulation legislation. An influential business magazine provided the following account of the first forum, that gathered in May 2014:

'The idea of turning this area of the country into a food basket for Colombia and even for the world generated many expectations, but the projects are suspended due to [...] Law 160 of 1994, which establishes restrictions on the regime of private property over land $[\ldots][\mathrm{T}]$ his is the main cause of paralysis for rural development in this region, and the prime concern of investors'. ${ }^{81}$

Addressing this claim required changing the law. This was a controversial move in the context of the time, with government negotiators in Havana agreeing a land distribution and pro-poor policy with the FARC. Between 2013 and 2015, there were three attempts to pass a bill that would regularize the situation of land accumulators. The first time, in November 2013, the bill was withdrawn, mostly due to critiques coming from the negotiating table at La Havana, and originating both from the FARC leadership and from government experts and negotiators. ${ }^{82} \mathrm{~A}$ second bill was retabled in October 2014. However, this version was withdrawn after a mobilization of the leftist opposition in Congress, allied with some figures of the presidential majority. The third attempt, introduced in April 2015, was finally successful. This was both linked to a very strong presidential support and to the fact that the peace negotiations were entering into its final phase, where the parties' attention was focused on complicated issues such as victim's rights and transitional justice.

The law created a new legal category: the Zones of Economic and Social Development Interest (Zidres). A set of extraordinary measures was granted to these zones, the most remarkable being the possibility of conceding public domain land. On paper, the law was not overtly opposed to the interests of small peasants, as it established guarantees in terms of previous consent. Local communities could join forces with corporations. The former providing land and the latter bringing capital. However, the law was a turning point, as it dismissed the idea that public land should exclusively benefit small farmers.

The Zidres act was granted the approval of the Constitutional Court in February 2017, after a heated and divisive debate within the Court. In January 2018, DNP established the national perimeter for the creation of Zidres. $67 \%$ of all the eligible areas correspond to Orinoco's Altillanura. ${ }^{83}$ In June 2018, the first Zidres zone was created in the municipality of Puerto López, in the heart of the Orinoco. The affected area covered 175.000 ha., and it is designed to be mostly dedicated to the production of palm-oil.

\section{The local reaction to the frontier narrative}

After Restrepo, Villegas and Mojica were ousted from the administration, the debate on landaccumulation remained surprisingly circumscribed to policy arenas such as DNP. There were

81 Dinero, "Altillanura busca salidas a las trabas de su desarrollo."

82 Interview with Andrés García, Special Advisor for land policies at the government’s negotiating team. Bogota, October 2017.

83 DNP, "CONPES 3917. Áreas de Referencia Como Insumo Para La Identificación de Las Zonas de Interés de Desarrollo Rural, Económico y Social (ZIDRES),” 39. 
several attempts to politicize the debate in Congress, but the government managed to defend the view that Zidres simply provided a set of technical measures aimed at delivering economic development that was to the benefit of rich and poor alike. The fact that Congressman Arias was defeated at the 2014 congressional elections certainly played a role.

However, the success of the frontier narrative can only be understood when looking more precisely at those primarily affected by the making of the frontier. A local look is here necessary. Two constituencies, cattle ranchers and small peasants, might be considered as primary stake-holders in the Zidres controversy. Their attitude and their political resources greatly differ. The cattle ranchers, who were seen by many policy-makers in Bogota as inefficient and archaic economic agents, ended up seeing the Zidres as an opportunity for consolidating their claim on land. Small peasants, while potentially threatened by the extension of agribusiness, lacked the capacity to give a national visibility to their grievances. This enormous inequality in terms of political resources is, at least in part, linked to the economic structures of land ownership in the region.

Land is extremely highly concentrated in Orinoco, as illustrated by an analysis of data provided by the 2014 agrarian census. ${ }^{84}$ In the seven municipalities of the Altillanura, 10\% of the properties registered in the census concentrate $81 \%$ of the land (excluding indigenous reserves, which are not covered by the Zidres perimeter). This appears even more acute when we focus on the top $1 \%$ of estates, i.e. the largest 56 properties registered in the census. These concentrate $60 \%$ of the rural land. This amounts to 5,6 over 9,2 million ha.

For the largest landowners, almost half of them cattle-ranchers, the primary threat was not corporate investment - but the state. As most of their estates are located on unregistered land, the law considers them to be irregular occupants. Within the early 2010s push for land-governance transparency, many of these ranchers were targetted by the Incoder inquiries on land accumulation. In 2013, as a result of the agrarian agreement recently reached by the FARC, Incoder was tasked with the mission of identifying possible sources of land that would be distributed to landless and land-poor peasants, then fulfilling a central feature of the 'Comprehensive rural reform' agreed in Havana. ${ }^{85}$ One of the possible sources were public lands unduly occupied by large land owners. A pilot project on public land's identification and reclaiming was launched for the municipality of Puerto Gaitán, located in the hearth of the Meta, one of Orinoco's provinces. According to the former division director in charge of these procedures, up to 900 cases of undue occupation were identified. ${ }^{86}$

From 2014, Incoder notified the ranchers of the ongoing procedures, many of which could lead to the expropriation of land that, although unregistered, was locally considered as legitimate private property. In reaction, a group of large landowners created the Dignillanos association, which was specifically aimed at defending the interests of ranchers threatened with eviction. The group was politically influential, as its spokeswoman was former Casanare governor Martha Gonfrier. ${ }^{87}$ By mid-2015, Dignillanos claimed to have registered more than 800 legal procedures. ${ }^{88}$ Dignillanos was

84 DANE, "Tercer Censo Nacional Agropecuario."

85 Interview with Miriam Villegas.

86 Interview with the former director of Incoder's agrarian procedures division, Bogota, November 2019.

87 Interview with Martha Gonfrier, Dignillanos spokeswoman, Villavicencio, July 2015.

88 Interview with Consuelo Devia, Dignillanos vice-president, Villavicencio, July 2015. 
active on different arenas. When I met them in July 2015, they had hired the services of a lobbying firm in Bogotá, with the aim of weighting on the debates in Congress.

My interviewees from Dignillanos were closely interested in the debates on the Zidres bill. As a matter of fact, for ranchers, joining forces with an agribusiness entrepreneur is not only a way of making money out of a favourable context; it is also a tactic aimed to protect their ownership claims. In 2015, while the bill was being examined for the third time in Congress, I observed a meeting between Senator Maritza Martínez's staff and three Dignillanos representatives. They agreed that an alliance between ranchers and corporations might be the best way of keeping state intervention at bay. ${ }^{89}$ The idea was simple: agribusiness investment was a government priority; if they were associated with agro-commodity projects, they would be protected against eviction. One month after this meeting, Senator Martínez-who was then one of the most visible figures of the region in Congress - voted in favour of the law.

What of the majority of the region's population, which is composed of small peasants and petty cattle-raisers? This is a highly vulnerable population. The smallest $20 \%$ of estates occupy less than $0,05 \%$ of the surface of the census. ${ }^{90}$ While there is a history of peasant activism in the western part of the region, where the Orinoco plains meet the Andes and the Macarena mountains, ${ }^{91}$ peasant organizations lack a social grounding in the largest part of the Altillanura. Due to settlement dynamics in this area, many of the rural poor live in isolated conditions, often surrounded by large ranches. ${ }^{92}$ This fragmentation is an important limitation for activism, which explains that opposition from local peasant movements to the Zidres law was inaudible at best. As a matter of fact, even in 2013, a year of massive mobilization for peasant organizations nationwide, there was very low protest activity in Orinoco..$^{93}$

In addition to that, the Zidres project never really emerged as a priority for national peasant movements. While the largest peasant organization, the National Association of Peasant Reserve Areas (ANZORC) vocally denounced the bill, they did not lead concrete actions to counter the project; they had a scarce presence in Orinoco, and their only local associates in the region were located in the Macarena mountains and were requesting the creation of Peasant Reserve Area. Providing support for this local initiative was ANZORC's priority when it came to Orinoco. ${ }^{94}$

\section{Conclusion}

This paper has borne on the case of Colombia's Orinoco savanna to reflect on the relation between post-conflict development policies and the production of agrarian frontiers. It showed how a frontier narrative is linked to a security consolidation policy that opened up new possibilities for agricultural investment. However, as investors were attracted by these opportunities, they relied on illegal strategies of land accumulation to circumvent a mildly pro-peasant legislation. The peace-making efforts launched by the government and supported by a number of other political actors posed a

89 Field notes, Villavicencio, July 2015.

90 DANE

91 Riveros Gómez, Pueblos arrasados.

92 Arias Vanegas, Ganadería, paisaje y región, 115.

93 Allain, "Défendre le territoire," 504.

94 Interview with ANZORC coordinator, Bogota, October 2017. 
threat to these irregular practices. While not directly linked to violent dispossession, they featured the much criticized lack of transparency and state regulation that had rendered possible wartime land grabbing. Nevertheless, the priority given by the government to its investor-friendly policy resulted in a reshaped and depoliticized narrative arguing that large corporations were the only business actors capable to overcome the obstacles to agriculture in Orinoco.

Through this case, this paper has pointed at two fundamental questions for the study of the political economy of peacemaking. First, it has made the case for a sociological understanding of the use and production of narratives regarding peace, as they enfranchise some actors, while disenfranchising others. Second, it has shown that the fundamental challenge faced by these narratives in warless times is the differentiation between spoliation and legitimate accumulation. The fixation of limits between the two is a fundamental endeavour for political actors in the aftermath of armed violence.

The Orinoco case is not an exception. In a highly similar fashion, capitalist exploitation projects all around Colombia are justified in the name of peace, security, and development. Transport and energy-generating infrastructures, oil-extraction areas and mining projects all promise prosperity to conflict-ridden territories and communities. While most of these designs remain unfulfilled, the capitalist utopia that they profess is not without effects. Even if their concrete results remain to be seen, these projects purport a corporatist economic model justified in the name of peace.

\section{Disclosure statement}

No potential conflict of interest was reported by the author.

\section{Acknowledgements}

A previous version of this paper was presented at the international conference 'Governance at the edge of the state', in Copenhagen and benefited from insightful comments from the public and participants. I am particularly thankful to Christian Lund for his invitation and hospitality. I finally wish to thank anonymous reviewers and editors at TWQ for their very rigorous but considerate evaluation.

\section{The author}

Jacobo Grajales is a professor of political science at the University of Lille, France, and Fellow of the Institut Universitaire de France. Having previously conducted research on the relationships between the state and armed groups in Colombia, he is now examining the links between postconflict politics and land policies, with a comparative perspective. His past and current research projects and publications can be retrieved at www.jacobo-grajales.net.

Email: jacobo.grajales-lopez@univ-lille.fr 


\section{Funding}

Funding for this research was provided by the Agence Nationale de la Recherche (ANR) under the contract ANR-17-CE41-0001, as well as by the Fondation de la Maison des Sciences de l'Homme, within the 'Nouvelles conflictualités' research programme.

\section{References}

Allain, Mathilde. "Défendre le territoire: la construction de solidarités internationales par les organisations paysannes colombiennes." PhD diss, Bordeaux University, 2016.

Arias Vanegas, Julio. Ganadería, paisaje y región. Una historia ecológica de la Orinoquia Colombiana. Bogota: Instituto Alexander von Humboldt, 2004.

Ballvé, Teo. "Grassroots Masquerades: Development, Paramilitaries, and Land Laundering in Colombia." Geoforum 50 (December 2013): 62-75.

. "Narco-Frontiers: A Spatial Framework for Drug-Fuelled Accumulation." Journal of Agrarian Change 19, no. 2 (2019): 211-24.

Baretta, Silvio R Duncan, and John Markoff. "Civilization and Barbarism: Cattle Frontiers in Latin America." In States of Violence, edited by Fernando Coronil and Julie Skurski, 33-74. Ann Arbor: University of Michigan Press, 2005.

Berdal, Mats, and Dominik Zaum, eds. Political Economy of Statebuilding: Power after Peace. London: Routledge, 2017.

Bjork-James, Carwil. "Hunting Indians: Globally Circulating Ideas and Frontier Practices in the Colombian Llanos." Comparative Studies in Society and History 57, no. 1 (2015): 98-129.

Courtheyn, Christopher. "Territories of Peace: Alter-Territorialities in Colombia's San José de Apartadó Peace Community." The Journal of Peasant Studies 45, no. 7 (2018): 1432-59.

Cramer, Christopher. Civil War is not a Stupid Thing: Accounting for Violence in Developing Countries. London: Hurst, 2006.

DANE. "Tercer Censo Nacional Agropecuario.” Bogota, 2014.

Dávila, Juana. "A Land of Lawyers, Experts and 'Men without Land': The Politics of Land Restitution and the Techno-Legal Production of 'Dispossessed People' in Colombia." PhD diss, Harvard university, 2017.

Debos, Marielle. Living by the Gun in Chad: Combatants, Impunity and State Formation. London: Zed Books, 2016.

Dinero. "Altillanura busca salidas a las trabas de su desarrollo." Dinero, June 3, 2014.

Distler, Werner, Elena B. Stavrevska, and Birte Vogel. "Economies of Peace: Economy Formation Processes and Outcomes in Conflict-Affected Societies." Civil Wars 20, no. 2 (April 3, 2018): 139-50.

DNP,. “CONPES 3797. Política para el desarrollo integral de la Orinoquía-Altillanura.” Bogota: January 12, 2014.

. “CONPES 3859. Política para la adopción e implementación de un catastro multipropósito rural-urbano." Bogota: June 13, 2016.

. "CONPES 3917. Áreas de referencia como insumo para la identificación de ZIDRES." Bogota: February 7, 2018.

Dudley, Steven. Walking Ghosts: Murder and Guerrilla Politics in Colombia. New York: Routledge, 2004.

Estrada, María, and Nadia Rodríguez. "La política de tierras para la población desplazada 20012011: de la protección a la restitución.” Estudios Socio-Jurídicos 16, no. 1 (2014): 75-119.

Fajardo, Darío. Las guerras de la agricultura colombiana, 1980-2010. Bogota: ILSA Instituto Latinoamericano para una Sociedad y un Derecho Alternativos, 2014. 
FAO. Concentración y extranjerización de tierras productivas en Colombia. Marco conceptual, legal e institucional, contribución a la aplicación de las Directrices Voluntarias sobre la Gobernanza Responsable de la Tenencia de la Tierra. Rome: FAO, 2017.

Garay-Salamanca, Luis Jorge, ed. El reto ante la trajedia humanitaria del desplazamiento forzado: reparar de manera integral el despojo de tierras y bienes. Bogota: Comisión de seguimiento a la política pública sobre desplazamiento forzado, 2009.

Garcia Trujillo, Andres. The Havana Peace Agreement and Colombia's Rural Development Policy. London: Routledge, 2020.

Gaviria Muñoz, Simón. "Presentacion. Plan maestro de la Orinoquia.” DNP, September 2016.

Gill, Lesley. A Century of Violence in a Red City: Popular Struggle, Counterinsurgency, and Human Rights in Colombia. Durham: Duke University Press, 2016.

Gómez, Carlos J. L., Luis Sánchez-Ayala, and Gonzalo A. Vargas. “Armed Conflict, Land Grabs and Primitive Accumulation in Colombia: Micro Processes, Macro Trends and the Puzzles in Between." The Journal of Peasant Studies 45, no 2 (2015): 255-274.

Grajales, Jacobo. "Land Grabbing, Legal Contention and Institutional Change in Colombia." Journal of Peasant Studies 42, no. 3-4 (2015): 541-60.

. "Violence Entrepreneurs, Law and Authority in Colombia." Development and Change 47, no. 6 (2016): 1294-1315.

Gobernar en medio de la violencia. Estado y paramilitarismo en Colombia. Bogota: Editorial Universidad del Rosario, 2017.

. "Losing Land in Times of Peace: Post-War Agrarian Capitalism in Colombia and Côte d'Ivoire." The Journal of Peasant Studies, 2020. DOI: 10.1080/03066150.2019.1691535

Gutierrez Sanín, Francisco, and Jenniffer Vargas Reina. El despojo paramilitar y su variación: Quiénes, cómo, por qué. Bogotá: Universidad del Rosario, 2016.

Gutiérrez-Sanín, Francisco, ed. ¿Qué hacer con el tierrero?: Tierra, territorio y paz sostenible. Bogotá: Editorial Universidad del Rosario, 2018.

Gutiérrez-Sanín, Francisco, Rocío del Pilar Peña-Huertas, and María Mónica Parada-Hernández. La tierra prometida: Balance de la política de restitución de tierras en Colombia. Bogotá: Editorial Universidad del Rosario, 2019.

Hall, Derek, Philip Hirsch, and Tania Murray Li. Powers of Exclusion: Land Dilemmas in Southeast Asia. Honolulu: University of Hawaii Press, 2011.

Jennings, Kathleen M., and Morten Bøås. "Transactions and Interactions: Everyday Life in the Peacekeeping Economy." Journal of Intervention and Statebuilding 9, no. 3 (July 3, 2015): 281-95.

Jones, M., E. Shanahan, and Mark K. McBeth. The Science of Stories: Applications of the Narrative Policy Framework in Public Policy Analysis. New York, NY: Palgrave Macmillan, 2014.

Klein, Naomi. The Shock Doctrine: The Rise of Disaster Capitalism. London: Penguin Press, 2008.

Li, Tania Murray. Land's End: Capitalist Relations on an Indigenous Frontier. Durham; London: Duke University Press, 2014.

. "Transnational Farmland Investment: A Risky Business." Journal of Agrarian Change 15, no. 4 (2015): 560-68.

Londoño, Rocío, ed. Tierras y conflictos rurales. Historia, políticas agrarias y protagonistas. Bogota: CNMH, 2016.

Lowenhaupt Tsing, Anna. "Natural Resources and Capitalist Frontiers." Economic and Political Weekly 38 (January 1, 2003): 5100-5106.

Machado, Absalón. La reforma rural, una deuda social y politica. Bogotá: Editorial Universidad Nacional de Colombia, 2009.

Machado, Absalón, and Donny Meertens, eds. La Tierra En Disputa. Memorias de Despojo y Resistencia En La Costa Caribe (1960-2010). Bogotá: Comisión Nacional de Reparación y Reconciliación. Área de Memoria Histórica, 2010. 
McKay, Ben M. "Democratising Land Control: Towards Rights, Reform and Restitution in PostConflict Colombia." Canadian Journal of Development Studies 39, no. 2 (2018): 163-81.

Maher, David, and Andrew Thomson. "A Precarious Peace? The Threat of Paramilitary Violence to the Peace Process in Colombia." Third World Quarterly 39, no. 11 (2018): 2142-72.

Meertens, Donny. Elusive Justice: Women, Land Rights, and Colombia's Transition to Peace. University of Wisconsin Pres, 2019.

Mesa Copartes Misereor. Desplazar y despojar. Estrategia para el desarrollo de la Orinoquía. Bogota: Impresol, 2017.

Moore, Jason W. Capitalism in the Web of Life: Ecology and the Accumulation of Capital. Verso, 2016.

OCHA, (UN Office for the Coordination of Humanitarian Affairs). 2019 Humanitarian Needs Overview: Colombia. New York, 2019.

Ojeda, Diana. "Green Pretexts: Ecotourism, Neoliberal Conservation and Land Grabbing in Tayrona National Natural Park, Colombia.” The Journal of Peasant Studies 39, no. 2 (2012): 357-75.

Ojeda, Diana, Jennifer Petzl, Catalina Quiroga, Ana Catalina Rodríguez, and Juan Guillermo Rojas. "Paisajes Del Despojo Cotidiano: Acaparamiento de Tierra y Agua En Montes de María, Colombia." Revista de Estudios Sociales, no. 35 (2015): 107-19.

Ottaway, Marina. "Rebuilding State Institutions in Collapsed States." Development and Change 33, no. 5 (2002): 1001-23.

Oxfam International. "Divide and Purchase. How Land Ownership is Being Concentrated in Colombia," September 2013.

Pantuliano, Sara, ed. Uncharted Territory: Land, Conflict and Humanitarian Action. Practical Action Publishing, 2009.

PARES. Más sombras que luces. La seguridad en Colombia a un año del gobierno de Iván Duque. Bogota, 2019.

Peluso, Nancy, and Christian Lund. "New Frontiers of Land Control: Introduction." Journal of Peasant Studies 38, no. 4 (2011): 667-81.

Pugh, Michael C., Neil Cooper, and Mandy Turner, eds. Whose Peace?: Critical Perspectives on the Political Economy of Peacebuilding. New York: Palgrave Macmillan, 2008.

Rasmussen, Mattias Borg, and Christian Lund. "Reconfiguring Frontier Spaces: The Territorialization of Resource Control." World Development 101 (January 1, 2018): 388-99.

Rausch, Jane M. A Tropical Plains Frontier: The Llanos of Colombia, 1531-1831. University of New Mexico Press, 1984.

. Territorial Rule in Colombia and the Transformation of the Llanos Orientales. Gainesville: University Press of Florida, 2013.

. The Llanos Frontier in Colombian History 1830-1930. Albuquerque: Univ of New Mexico Pr, 1993.

Restrepo, Juan Camilo. Implementación de La Politica Integral de Tierras (2010-2013). Bogotá: Ministerio de Agricultura, 2013.

Restrepo, Juan Camilo, and Andrés Bernal. La cuestión agraria: tierra y posconflicto en Colombia. Bogota: Penguin Random House, 2014.

Reyes, Alejandro. Guerreros y campesinos. El despojo de la tierra en Colombia. Bogotá: FESCOL/ Norma, 2009.

Richards, Paul, ed. New War: An Ethnographic Approach. Oxford: James Currey, 2005.

Riveros Gómez, Catalina, ed. Pueblos arrasados. Memorias del desplazamiento forzado en el Castillo (Meta). Bogotá: CNMH, 2015.

Roe, Emery. Narrative Policy Analysis: Theory and Practice. Durham: Duke University Press, 1994.

Salinas Abdala, Yamile. "El caso de Colombia." In Dinámicas del mercado de la tierra en América Latina y el Caribe: concentración y extrajerización, edited by FAO. Rome: FAO, 2012. 
Schlimmer, Sina. "Talking 'Land Grabs' Is Talking Politics: Land as Politicised Rhetoric during Tanzania's 2015 Elections.” Journal of Eastern African Studies 12, no. 1 (2018): 83-101.

Somo, and Indepaz. Reconquering and Dispossession in the Altillanura. The Case of Poligrow. Amsterdam: Centre for Research on Multinational Corporations, 2015.

UPRA. "Planificación Regional: Altillanura." Bogota, 2014.

Verdad Abierta, Verdad. "Grupo Aliar-La Fazenda responde por las tierras de 'El Brasil', en Puerto Gaitán." Verdad Abierta, December 2, 2013. Online: https://verdadabierta.com/grupo-aliarla-fazenda-responde-por-las-tierras-de-el-brasil-en-puerto-gaitan/. Last accessed 12 March 2020.

Watts, Michael. "Accumulating Insecurity and Manufacturing Risk along the Energy Frontier." In Research in Political Economy, edited by Susanne Soederberg, 31:197-236. Emerald, 2016.

Wolford, Wendy et al. "Governing Global Land Deals: The Role of the State in the Rush for Land." Development \& Change 44, no. 2 (2013): 189-210. 